\title{
The Pyramid of Values: Value-based Leadership Lessons based on teachings from Bhagavad Gita Chapter 13
}

\author{
Nanjundappa S Harshavardhana ${ }^{1}{ }^{*}$, Kuravanka G Srinivas ${ }^{2}$ \\ ${ }^{1}$ MS, FRCS, Dumfries \& Galloway Royal Infirmary, Dumfries, United Kingdom \\ ${ }^{2}$ MD, FRCA, Leicester Royal Infirmary, Leicester, United Kingdom \\ *Corresponding author contact details: Dept. of Orthopaedics, A75 Cargenbridge, Dumfries- DG2 8RX, United Kingdom, \\ +44-7711880593; email: nharsha@outlook.com \\ https://doi.org/10.36018/dsiij.v18i.213
}

\begin{abstract}
Among the purposes the Bhagavad Gita is studied some have spiritual, theological and religious perspective. The Master- the lord Srikrishna through his preaching convincingly manages to motivate disciple Arjuna to realize his duty to fight his enemies with determination constitutes collection of 700 verses known as Shrimad Bhagvad Geeta. It is considered as 'India's book of Answers' to all the problems of human-life. Bhagavad Gita has inspired and guided generations for ages. Bhagavad Gita preaches three-fold path i.e. i) Action (Karma), ii) Devotion (Bhakti), and iii) Wisdom (Jnana) for finding Swadharma (duty of each-self). Wisdom from the Bhagavad Gita is increasingly recognized in the field of leadership and management.

It emphasizes that the core of leadership lies in one's character and is influenced by 'Value' systems. The 13th chapter of Srimad Bhagavad Gita is called 'Kshetra-Kshetrajna Vibhaga Yoga'. The study have classified 20 values described in the verse 7-11 into four categories and proposed a pyramid of values. Incorporating these teachings of Bhagavad Gita would facilitate a leader to be free of bias, observe equanimity and make wise decisions leading to contentment and inner peace. This whole process of attaining value-system through selfrealization is the ultimate state for leadership. The leadership values are integral part of self-realization achieved through practicing of these values.
\end{abstract}

Keywords. Bhagavad Gita, Leadership, Management, Values, Wisdom

\section{Introduction}

The Bhagavad Gita is a timeless classic of ancient Indian philosophy that is primarily studied for various purposes ranging from spiritual, theological, religious perspective and many more. It is a collection of 700 verses that is organized in 18 chapters that is a part of world's longest epic 'The

Mahabharata'. Bhagavad Gita is a conversation between Lord 'Srikrishna' as a Master and warrior prince 'Arjuna' as a disciple, who has lost his purpose on the battlefield. Master- the lord Srikrishna through his preaching convincingly manages to motivate disciple Arjuna to realize his 
duty to fight his enemies with determination. Arjuna represent the mind of today's human whose lifestruggle is also like a battle field in which one needs to find self-duty (Swadharma).

Bhagavad Gita has left a lasting legacy inspiring mankind over three millennia that have valuable leadership lessons hidden in it. In the development of leadership role, work needs to be undertaken that has explored the role of psychological, ethical, moral, philosophical-spiritual aspects and value systems. The message of the Bhagavad Gita is still relevant in contemporary world and it is a nonsectarian text that carries a universal message without any religious affiliation.

With evolution, the war has only shifted from battlefield to inner-personal and family conflict as well as in social-life i.e. boardroom of corporations, organizations, parliaments, etc, for preserving the values. The value system mentioned in the Bhagavad Gita has perfect inspirations that harmonize the need of each individual entity whether as employees, corporations and nations.

A leader's character is influenced by 'Value' systems and three key 'Personality' traits [i.e. i) Sattva (good virtues); ii) Rajas (passion) and ii) Tamas (ignorance)]. Great leaders like Mahatma Gandhi and Nelson Mandela are few of great examples whose leadership was based on the teachings of the Bhagavad Gita value system.

Several management experts have increasingly acknowledged contribution of teachings of Bhagavad Gita in leadership and management (Chaterjee 2012 (1), Roka 2018 (2), Senge 1990 (3), Senge 2005 (4), Jaiswal 2014 (5). Eminent luminaries of the $20^{\text {th }}$ century viz. Aldous Huxley,
Henry D Thoreau and Ralph Waldo Emerson have all cited the Bhagavad Gita in their works (Mishra 2019 (6) and Steiner 2009 (7)). Thus these studies indicated that a true leader attains higher status by incorporating spiritual values, practicing value-based leadership, observing altruism and conducting oneself with humility. The present study aims to address the value system required in a leader based on Bhagavad Gita's teachings

\section{Methodology}

The study undertook an exploratory journey of all 700 verses with special reference to Chapter 13, attempting to identify the leadership skills and value systems that the Master Srikrishna preached his disciple Arjuna.

The $13^{\text {th }}$ chapter of Srimad Bhagavad Gita is called 'Kshetra-Kshetrajna Vibhaga Yoga'. The supreme lord describes the concept of field, knower of the field and consciousness. The supreme soul The 'Brahman' is eternal, unchangeable, non-destructible and pure. The lord describes the means to attain the knowledge of this 'Brahman' and virtues of the 'Erudite'. These are in the form of twenty values and are explained in five verses (7 to 11) that have profound leadership lessons with invaluable wisdom. This monograph is a brief synopsis of these 'Twenty Values' and attempts to provide a concise explanation of them (Saraswati 2007 (8)). The five verses that describe these values verbatim in English language are illustrated in Table 1.

\section{0-values with profound leadership lessons from Chapter 13}

The twenty values from verse $13 / 7$ to $13 / 11$ are subdivided into four categories as following:

1. Values of 'Aachara' (Conduct or Behaviour)

2. Values of 'Bhavana' (Attitude or Character) 
3. Values of 'Parivarthana' (Transformational or Metamorphosis)

4. Values of 'Athyanta' (Ultimate or Pinnacle).

\begin{tabular}{|c|c|c|}
\hline \multicolumn{2}{|c|}{ No Citation } & Sanskrit Verses (verbatim in English) \\
\hline 1 & & $\begin{array}{l}\text { amānitvam adambhitvam ahimsā kṣhāntì ārjavam } \\
\text { āchāryopāsanam śhaucham sthairyam ātma- } \\
\text { vinigrahaḥ }\end{array}$ \\
\hline 2 & $13-8$ & $\begin{array}{l}\text { indriyārtheșhu vairāgyam anahankāra eva cha } \\
\text { janma-mrityu-jarā-vyādhi-duḥkha- } \\
\text { doṣhānudarśhanam }\end{array}$ \\
\hline 3 & $13-9$ & $\begin{array}{l}\text { asaktir anabhișhvañgaḥ putra-dāra-gṛihādișhu } \\
\text { nityaṁ cha sama-chittatvam ișhțānișhțopapattișhu }\end{array}$ \\
\hline 4 & $13-10$ & $\begin{array}{l}\text { mayi chānanya-yogena bhaktir avyabhichāriṇī } \\
\text { vivikta-deśha-sevitvam aratir jana-sansadi }\end{array}$ \\
\hline 5 & $13-11$ & $\begin{array}{l}\text { adhyātma-jñāna-nityatvami tattva-jñānārtha- } \\
\text { darśhanam } \\
\text { etaj jñānam iti proktam ajñānam yad ato 'nyathā }\end{array}$ \\
\hline
\end{tabular}

Table 1: The five verses in Chapter 13 of The Bhagavad Gita

The study have chosen to classify these twenty values into four broad domains or categories for ease of remembrance, understanding and sustain one's interest in reading this article. It was perspective of authors that the first eight values are related to one's behaviour or conduct which bring a gradual change in one's attitude or character expressed as a set of seven values. These fifteen values are responsible for a transformational change in an individual's personality as a part of continuously evolving spiritual process and comprises of three values. Thus, painstakingly gained or nurtured eighteen values finally culminate in acquisition of two pinnacle or ultimate values that completes a process of self-realization. This self-realization is the ultimate state for leadership; Lord Srikrishna himself demonstrated them through his life. The leadership values are integral part of self-realization achieved through practicing of these values. This whole process of attaining value-system through selfrealization is depicted in Figure 1.
In addition, Bhagavad Gita also recognize the the role of mentors to identify such talented personnel and nurture them during formative years with such values. With sufficient training, will-power and constant practice one can transform into a good leader leading and influencing masses with his conduct and actions.

\section{Values of Aachara (Conduct or Behaviour)}

Amanitvam (humility)

It is genuine humility and absence of 'Conceit'. It refers to self-awareness and self-acceptance of one's strengths (and weaknesses). Amanatvam involves the elimination of demand on others to shower adulation and respect. Cultivating this trait keep one's Ego under check and eliminates mutual hurt, friction and an agitated inner-self. One should let 'Skills-set' speak for itself and let our actions command respect instead of demanding it. An approach wherein one attributes success to 'being fortunate to have the unique opportunities to achieve it' cultivates a mind of 'Prasada Buddhi' (will of divine) which further nurtures humility.

\section{Adhambhitvam (unpretentiousness)}

'Dhamba' refers to an inflated sense of self-pride and self-glorification. It involves fabricating our abilities and accomplishments and a form of selfdelusion. Adhambhitvam is a virtue that involves the ability to perceive oneself honestly and project this true 'self' to the society. Plasticising this trait keeps one's arrogance under check and provides an inner strength to be self-confident. There is no room for hypocrisy as the real person is just plain and simple. The mind of a complex person is in conflict with the self which could be a hurdle for the mind to acquire other 18 values. 


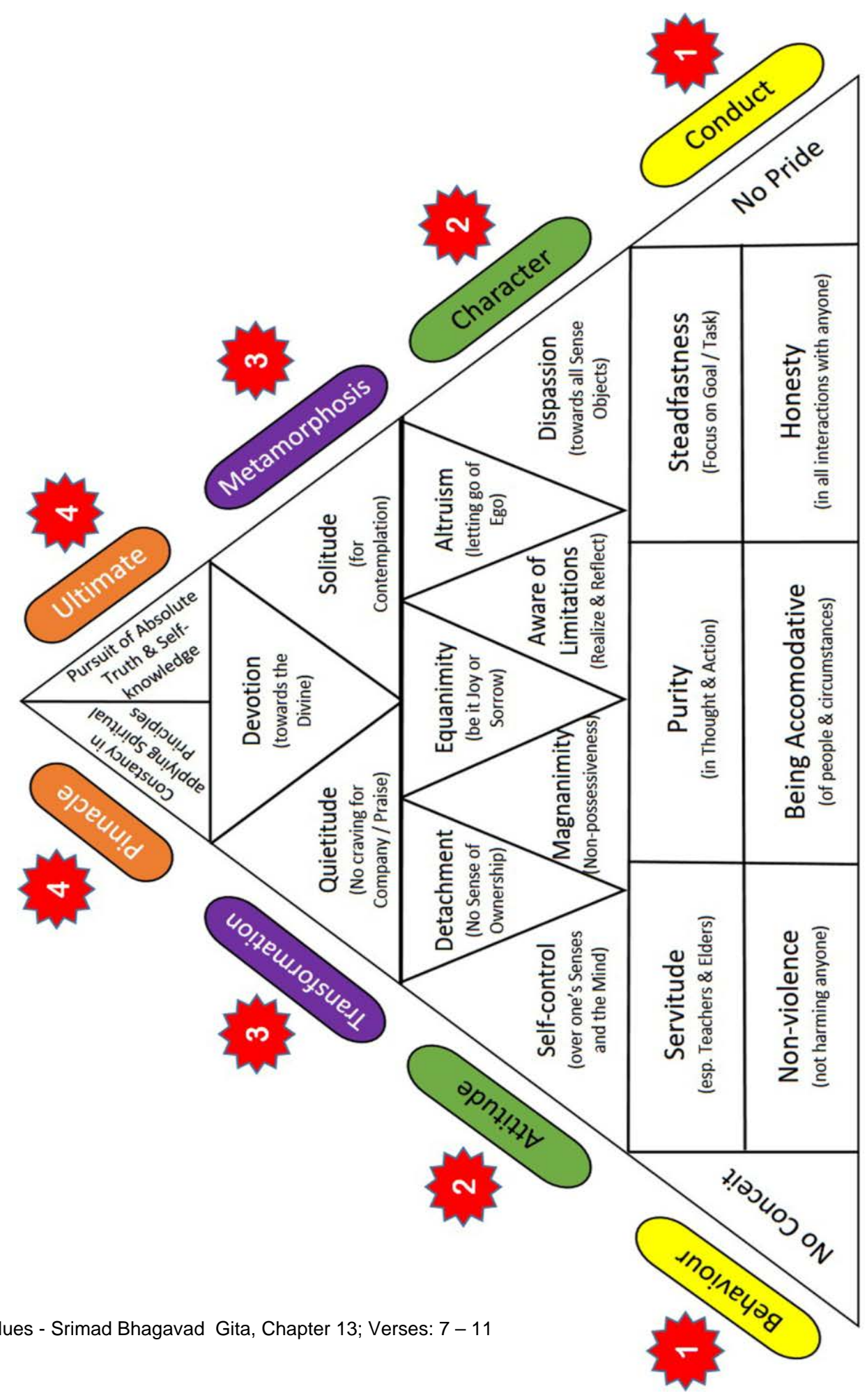

Ahimsa (non-violence)

This trait refers to not hurting or harming others either in the form of thought, word or action. The duty of the strong / powerful is to protect and nurture the weak/vulnerable. Humans are gifted with a 'power of choice' unlike animals if exercised makes one sensitive to the feelings of others. It sows the seeds of compassion, loving kindness and 
camaraderie. It gives one a perspective to appreciate and value of others' needs / requirements in-addition to one's own.

\section{Kshanti (patience)}

This refers to 'Forbearance' and the spirit of an individual to be accommodative of others in challenging situations / confrontations. It helps in developing a cheerful personality and is an excellent practical exercise in cultivating patience. It prepares one's mind to reduce the expectations from others and gleefully accept all the surprises in relationships. It is an ability of an individual to be merciful, forgiving and practice gratitude. Incorporating this as a part of one's personality eliminates the need to expect and compel people to change to become more pleasant / acceptable to us.

\section{Arjavam (simplicity)}

It is a quality of being upright, honest, truthful and transparent in thought, word and action wherein an individual conducts oneself with integrity. Nonalignment in any of these three domains creates a disintegrated inner-self that is ridden with guilt, selfdoubt and shame. A righteous individual is fearless to face anything and not in conflict with the self. Emphasis on this trait is so much that it has found its way in the Indian national emblem (insignia of India) inscribed as 'Satyam Eva Jayate' i.e. Truth alone Triumphs.

\section{Acharyopasanam (Service to the Guru)}

This literally means 'meditating on the Teacher'. The 'Guru' is the individual who imparts one with the knowledge of the 'Self' that is the gateway / foundation of all knowledge to follow. It involves an attitude of cultivating reverence towards one's teachers or elders and retaining those teachings in one's heart. The student is recommended to develop qualities of surrendering one's personal ego, willingness to give without the fear of being exploited or any demand for return with unswerving devotion or loyalty. The supreme lord recommends choosing one's Guru carefully as the teacher who is surrendered to 'has no need of this surrender' from the student and the student alone is the beneficiary by such an act.

\section{Saucham (cleanliness)}

This trait refers to cleanliness or purity (more so internal-inner) in every aspect of one's living. It involves purity in our thoughts, motives, intentions, passions and urges. It is an attempt to eliminate any form of greed, jealousy, contempt, and blame on others. An impure or unclean mind is filled with conceit, deception, resentment, despair and holding someone accountable to one's state of affairs. Nurturing this trait is helpful in overcoming such negative emotions and developing 'Pratipaksha Bhavana' (i.e. choosing to entertain opposite point of view) that would nip jealousy in the bud (Saraswati 2015 (9)).

Such an approach erases all forms of hatred in one's mind on a daily basis and paves way for empathy and understanding others or their view-points. If there is a choice between 'being Right Vs. being Kind', one would choose to be 'Kind by default' keeping one's anger under check.

\section{Sthairyam (persistence)}

This refers to a quality of dogged determination and perseverance or resolve amidst adversity and obstacles. It is a state of mind that his focussed on goal or task towards a worthwhile objective. Such a mind would have no room for laziness and procrastination. None of the distraction and hurdle is too big to overcome for a steadfast mind. 


\section{Values of Bhavana (Attitude or Character)}

Atmavinigrahah (self-restraint)

This trait involves a degree of self-control over one's mind and senses. It shapes one's ways of thinking and eliminates impulsivity, pre-conceived notion of others and prejudices. The mind is disciplined at such a level where ill-thoughts, if any arise, can not disturb 'Chitta-ekagrata' (a single pointed mind with a given line of thinking). When one is alert and conscious of thoughts as they arise, the actions becomes spontaneous. An individual with this trait is compared to a wise tortoise which withdraws its limbs from danger wherein the mind is capable of exercising control over sense organs.

Indriyarthesu Vairagyam (renunciation of selfobjects)

It is a state of mind that has transcended the struggle for control and has developed an attitude of dispassion for sense objects. It involves degree of restraint over one's desires. A mind bathed in Vairagyam doesn't fall prey to mundane temptations as bait. Worldly pleasures lose the power to distract it. It is a serene state of mind that is born out of sheer understanding and characterized by total objectivity without any subjective distortion.

\section{Anahankara (Absence of egotism)}

This trait and the second Aachara value 'Adhambhitvam' go together. Anahankara refers to elimination of ego. It is the ego that binds us to our emotions, fears, actions and possessions. The ego is a good servant but a bad master and if unchecked, can lead to chaos, self-exaltation, birth of impure thoughts and downfall. A mind of Anahankari sees divine presence in everyone at all times in all ways everywhere. It dispels ignorance paving way for acquiesce of self-knowledge.
Janma-Mrthyu-Jara-Vyadhi-Dukha-

Dosanudarshanam (perception of birth, death, old age, and disease)

This trait refers to impermanence of things in life and the reality of realizing our limitations as mortals. It is a reminder of the fact that birth and death are two faces of the same coin and that old age, suffering due to illness or chronic ailments is inevitable and a part of life that is a wholesome package. Nurturing this attitude prepares the mind to embrace it and emphasizes the importance of 'living in the present moment' instead of worrying about it. It is the reminder of the fact that all events in life are temporary and the only constant thing is 'Change'.

\section{Asaktih (detachment)}

This is a wonderful trait or attitude to cultivate where one is detached from the results of the action. It introduces the concept of 'Karma phala tyaga' which recommends one to perform one's duties to the best of one's abilities without worrying about the results or outcome. It nurtures a quality of detachment from the 'Sense of ownership' as we are at best caretakers of everything we own or possess. If Vairagyam was an attitude of dispassion towards sense objects, Asaktih is the next level wherein the relationship with those sense objects and recommended outlook towards them is highlighted.

Anabhisvangah-Putra-Dara-Grihadishu (freedom from entanglement from family life)

Abisvangah is defined as a trait of intense attachment or excessive affection towards one's close relations with child, spouse, family members, house, etc. This is a virtue that recommends absence of such intense possessiveness and discarding mental identification of the 'Self' with materialistic possessions and with closed ones. It is however not to be misunderstood as abandonment of one's duty 
or care. It only means due care is exercised with compassion, affection with objectivity and dispassion without any expectations.

\section{Nityam-Samachittatvam (Even-mindfulness with} regard to that which is desirable and undesirable) It refers to a balanced internal state of mind that is in 'Equanimity' i.e. not affected by sorrow or joy and happiness or adversity. It is not to be misunderstood as indifference, apathy or a mind that is this lacking emotions. An individual in Samachittatvam has a mind that is indifferent to desirable or undesirable situations and reduces any pressing situation to simple facts that facilitates one to make rational and objective choices. It is a state where the mind is calm and clear that makes best decisions devoid of any bias, nepotism and prejudice. Cultivating such a frame of mind eliminates subjectivity where one behaves in a fair manner in any situation.

\section{Values of Parivarthana (Inner transformation or Metamorphosis)}

Ananya Yogena Bhakti (unswerving devotion to supreme force)

This is a trait characterized by unswerving devotion to the supreme divine facilitated by subjugation of one's ego. This steadfast devotion coupled with an attitude of 'Prasada Buddhi' makes one to view the result of all our actions as a blessing received directly from the hands of the Lord. Any situation of life is perceived as a 'Prasada' (blessing) from the divine. This attitude frees the mind from any kind of reaction towards anyone or anything, and all is gracefully accepted as 'Daiva Ichche' (benevolent universe chose it to be this way).

Vivikta-Desa-Sevitvam (residing in secluded places) It is a trait where one is 'free from the fear of loneliness' and the mind doesn't seek an outlet through companionship. The individual loves oneself and has the intrinsic ability to accept oneself by eliminating the reluctance to face the Self. Such a mind is prepared for pursuit of higher goals when serenity and tranquillity are firmly established. Such an attribute is a pre-requisite for acquiring the knowledge of the self. The time spent in solitude is soaked with devotional and spiritual thoughts that bring out one's creativity.

Aratih-Jana-Samsadi (detachment from social gathering)

This trait refers to lack of craving for company or society despite being a part of it and living amidst it. It introduces a concept of 'attached detachment' where one develops a state of composure nurturing subtle sensitivity towards others and their behaviour where one is not being dependent on others for inner peace and happiness. Such an individual neither revels nor hates the company of people and is engaged with the society as a service to the supreme. Quietude is both relaxing and refreshing that provides 'rest' to the mind engulfed in cosmic chaos of uncertainty and unpredictability.

\section{Values of Athyanta (Ultimate or Pinnacle ones)}

The final two values described by the supreme Lord are interpreted differently by different schools of thoughts i.e. Dvaita, Advaita Vishitadvaita, Mimamsaka, etc. is difficult to summarize objectively. However, the present study attempt to explain through Advaita Vedantic understanding where $20^{\text {th }}$ value is described first than $19^{\text {th }}$ value.

Tattva-Jnanartha-Darshanam (keeping in sight the purpose)

The word 'Tattva' means truth and is a trait that become natural to an individual who has assimilated the above 18 values. Humans are blessed with 
faculty of thought and wisdom unlike animals which gives one a unique edge to question oneself the purpose of existence. All human pursuits are characterized under four main domains: i) Dharma (Righteousness); ii) Artha (Security); iii) Kama (Desires) and iv) Moksha (Liberation). This value instils a notion that the basic purpose of life is 'Moksha' (i.e. emancipation) as no amount of accomplishments and achievements provides lasting satisfaction. It is 'Moksha' alone that liberates the 'Self' where one frees oneself from a sense of inadequacy and incompleteness with a 'burning desire to be rid of the desires'. The trait literally means a 'steadfast pursuit of keeping Moksha always in sight and channelling all efforts towards its attainment. Such an individual transforms into a 'Mumukshu'. One begins to realize that all worldly material things are limited and transient and knowledge of the self alone that is limitless and liberating. Over a period of time, a 'Mumukshu' evolves into a 'Jignasa' i.e. the one who has a mind that is bent on inquiry for the sake of nothing but knowledge.

Adhyatma-Jnana-Nityatvam (steadiness in selfrealization)

The final value trait goes hand-in-glove with 'Tattva Jnana' that means constancy in pursuit with regular practice of the knowledge of the Self. It recommends an approach of 'Sravana - Manama Nidhidhyasana' i.e. listen, reflect and contemplate to dwell on the above concepts all the time as a continuous process in an effort to be one with the supreme existence. It starts from practising these virtues as much as possible for self-refinement as the final step of leadership values.

\section{Discussion}

Mere theoretical knowledge of these twenty values is not helpful for leadership. One should practice above attributes in their lives so that it is integrated into personality. The knowledge of the self is to be 'Lived' rather 'Learnt'. An individual in this path is not clouded by subjective conditions and undismayed by external adversities, which is essential requirement for good leadership. The complex interplay between 'Jiva - Jagat - Ishwara' (Self - World - Supreme) is realized as nothing but One (Tat - Tvam - Asi). These traits facilitate one to move away from 'Subjectivity' towards 'Objectivity' and exercise control over impulses, senses and judgements. A person is weeded out all impurities and becomes an 'Asangi' (i.e. the one who is detached from everything but the Truth). The sub-division of twenty values into four domains is the result of authors' perspective for the ease of understanding value system for leadership based on the self-realization teachings of chapter 13/7-11. It also facilitated to propose to create a four-tiered pyramid and summarize Srikrishna's teachings into a graphical representation (Figure 1) which needs further analysis and validation. These values are 'Qualitative' ones are not directly measurable on quantitatively. The acquisition of these traits happen simultaneously and sequentially both horizontally and vertically in the four-tiered pyramid through Karma (action), Bhakti (devotion) and Jnana (wisdom) nurturing attributes in a leader who works selflessly for the welfare of all and becomes a rolemodel for others.

The present study has several limitations. The study attempted to summarize five verses of Chapter 13 i.e. 7 to 11 of the Bhagavad Gita in a concise manner to address values which are helpful building leadership values. The study does not elaborate the 
process how incorporating this values in life would generate the great leaders rather it summarize as basis of self-realization leading to leadership lesions. In addition, the study also did not explain how it will impact and benefit the society, community, organization and nation leadership need and the challenges encountered in observing or following these on an individual level or as organizational level which is out of present study's scope. Despite these inherent limitations, the present study is one of its kinds that have attempted to summarize Srikrishna's teachings pictorially in the form of a pyramid value lessons for leadership.

\section{Conclusion}

In-summary the Bhagavad Gita teaches that good leadership requires inner-balance and path to selfrealization. Bhagavad Gita is a manual that builds confidence and removes ignorance, delusion and self-doubt. By routinely practicing the value-based teachings of the Bhagvad Geeta an individual would exercise control over one's senses, tames one's anger and conquer fear. The central theme of the Bhagavad Gita is to renounce the attachment to the results of actions (Karma Phala Tyaga), which is essential for good leadership practices. Such an approach would facilitate an individual to accept any outcome of result desirable or undesirable with grace and humility, which would help leader to take decisions without being distracted. The proposed four-tiered 'Pyramid of Values' is helpful as a tool for proficient and effective leaders with their real identity (Figure 1). It would also transform an individual to a heightened being with moral sensitivity, behaviour and character. Life of 'Srikrishna' also demonstrated the same that a good leader is 'not dependent on anyone' but 'makes oneself dependable for everyone'. Such a person would handle criticism and accolades with equanimity and work tirelessly for the greater good of the corporation over one's own self-interest by adopting an open-minded and non-judgemental approach. The above concepts are both energy conserving, mind purifying and minimizes the 'Burnout from Stress' at the workplace. Such an individual would transcend and attain higher state of consciousness with dissolution of ego. They would leave a lasting legacy like great self-realized leaders Buddha, JesusChrist, Srikrishna, Acharya Shankar, etc whose teachings continues to inspire mankind over several generations (Hawkins 2015) (10).

\section{Acknowledgement}

We would like to thank Prof. Bindkumar Agarwala and Prof. B Mahadevan for their mentorship, guidance and feedback.

\section{References}

1. Chatterjee, D. Timeless leadership: 18 leadership sutras from the Bhagavad Gita. Chichester, UK: Wiley, 2012.

2. Roka, P. Bhagavad Gita on effective leadership: Timeless wisdom for leaders. Ahmedabad: Jaico Pub. House, 2018.

3. Senge, P. M. The fifth discipline: The art and practice of the learning organization. New York: Doubleday, 1990.

4. Senge, P. M. Society for Organizational Learning Presence: An exploration of profound change in people, organizations, and society. New York: Doubleday, 2005.

5. Jaiswal, U., \& RAO, K. N. Leadership Lessons from Bhagavad Gita. Dev Sanskriti Interdisciplinary International Journal, 2014;3:19-24. https://doi.org/10.36018/dsiij.v3i0.32

6. Mishra, V. The gothic sublime. SUNY Press. New York, 2019.

7. Steiner, R., McDermott, R. A., et al. The Bhagavad Gita and the West: the esoteric significance of the Bhagavad Gita and its relation to the epistles of Paul. Forest Row, Steiner Books, 2009.

8. Saraswati, D. The value of values. Chennai: Arsha Vidya Research and Publication Trust, 2007.

9. Saraswati, D. Bhagavad Gita home study course: Vol 1 - 9. Chennai: Arsha Vidya Research and Publication Trust, 2015.

10. Hawkins, D. R.. Transcending the levels of consciousness: The stairway to enlightenment. West Sedona: Veritas Publishing, 2015 